CANADIAN LINGUISTIC ASSOCIATION
ASSOCIATION CANADIENNE DE LINGUISTIQUE

ANNUAL MEETING PROGRAMME

PROGRAMME DES JOURNEES D'ETUDE

University of Alberta

Edmonton

June 12-13 Juin

Thursday, June 12 / Jeudi 12 juin :

9.30 a.m. Executive Meeting / Réunion du bureau

10.00 a.m. General Business Meeting / Assemblée générale

12.30 p.m. Luncheon / Déjeuner

2.30 p.m. Papers / Communications (1)

1. P. D. Drysdale (Memorial U.), "Some Problems in Newfoundland Speech Investigation." (30 min.)

2. O. Starchuk (Alberta), "The Effects of Slavonic on the Roumanian Language Between the VI and XII Centuries." (30 min.)

3. D. Hamilton (CMR), "Notes on Montreal English." (25 min.)

4. W. Suttles (UBC), "Some Theoretical Implications of the History of Chinook Jargon" [with tapes]. (15 min.)

5. J. B. Rudnyckyj (Manitoba), "Two Systems of Slavistic Transliteration for Canada." (20 min.)

6. Discussion.

Friday, June 13 / Vendredi 13 juin :

9.30 a.m. Papers / Communications (2)

1. P. Svarich, "The Slavic Linguistic Atlas of Alberta." (20 min.)

2. R. Baker (UBC), "Leaving One's Language Alone." (20 min.)

3. M. H. Scargill (Alberta), "The Dictionary of $\mathrm{Ca}-$ nadian English on Historical Principles : A Plan of Operation." (45 min.)

4. Discussion.

2.30 p.m.

1. E. R. Seary (Memorial U.), "The French Element. in Newfoundland Place Names." ( $30 \mathrm{~min}$.)

2. D. G. Pitt (Memorial U.), "John Locke and Language." ( $30 \mathrm{~min}$.)

3. G. Marsh (UBC), "Some Highlights of Aleutian Phonology." (30 min.)

4. P. Daviault (Ottawa), [to be decided later].

5. Discussion. 


\section{INTRODUCTION TO LINGUISTIC STRUCTURES}

\section{Archibald HIII}

\section{University of Texas}

This new linguistic text is now available. We will be happy to send an examination copy to you if you wish to consider this book for class use.

Chapter headings include : What is Language?; Stress, Juncture, Pitch; Consonants; Phoneme and Allophone; Vowels and Vowel Nuclei; Phonotactics; Morphemics; Morphotactics; Inflection; Form Classes Marked by Derivational Morphemes; The Structure of Free Phrases; Verb Phrases (2 chapters); Modifying Phrases; Main Sentence Elements (3 chapters); Simple Sentences; Complex Sentences (2 chapters); and Beyond The Sentence. Appendix A, ESKIMO - A Grammatical Sketch. Appendix $B, L A T I N$.

\section{Other Texts Available}

THE STRUCTURE OF ENGLISH. Charles C. Fries. A pioneering linguistic analysis of the struoture of the language. More than fifty hours of mechanically recorded conversations furnished the materials for analysis . . . . . . . . . . . Price : $\$ 4.25$

PATTERNS OF ENGLISH. Paul M. Roberts. Using recent findings in linguisties, the author has developed a completely new method of teaching the English language to students in upper years of high school . . . . . . . . . . . . . Price : $\$ 2.88$

- LANGUAGE IN THOUGHT AND ACTION. B. I. Hayakawa, in consultation with Basil $H$. Pillard. A reappraisal and further development of the semantic principles presented in LANGUAGE IN ACTION $\ldots \ldots \ldots \ldots \ldots$

- POWER OF WORDS. Stuart Chase. About the latest findings in communication, semantics, and meaning. .. Price : $\$ 3.00$

\section{W. J. GAGE LIMITED}

